\title{
Factors Affecting the Induction of Sexual Reproduction in Phytophthora parasitica by $P$. colocasiae
}

\author{
By J. Y. YU ${ }^{1}$, H. S. CHANG ${ }^{2}$ AND W. H. KO ${ }^{3 *}$ \\ ${ }^{1}$ Plant Pathology Laboratory, National Taiwan University, Taipei, Taiwan \\ ${ }^{2}$ Institute of Botany, Academia Sinica, Taipei, Taiwan \\ ${ }^{3}$ Department of Plant Pathology, University of Hawaii, Beaumont Agricultural Research \\ Center, Hilo, Hawaii 96720, U.S.A.
}

(Received 5 September 1980)

\begin{abstract}
When Phytophthora colocasiae $\left(\mathrm{A}^{2}\right)$ was used as a hormone producer and $P$. parasitica $\left(\mathrm{A}^{1}\right)$ as a hormone receptor, no sex organs of $P$. parasitica were observed in matings lasting for $7 \mathrm{~h}$, but the amount of hormone produced was sufficient to stimulate the production of 341 oospores $\mathrm{cm}^{-2} 6 \mathrm{~d}$ later. The maximum induction of sex organs was reached in matings lasting $48 \mathrm{~h}$. Hormone production was inhibited by light, but the effect of light on oospore development was small. Temperatures of 10 and $15^{\circ} \mathrm{C}$ inhibited the growth and hormone production by $P$. colocasiae, and prevented $P$. parasitica from forming new sex organs after stimulation by hormone. The effect of temperature on hormone production differed from that on oospore formation. Hormone production was poor at $30^{\circ} \mathrm{C}$, but oospore development was good at this temperature.
\end{abstract}

\section{INTRODUCTION}

Direct evidence for the hormonal regulation of sexual reproduction in both cross-inducing and self-inducing species of Phytophthora was obtained by Ko $(1978,1980)$ using a polycarbonate membrane method. The results of membrane matings demonstrate that the sexual reproduction in Phytophthora is controlled by hormones and receptors. For the cross-inducing species of Phytophthora it was postulated that the initiation of oospore formation by $\mathrm{A}^{2}$ isolates depends on the presence of an active receptor to the sex hormone $\alpha^{1}$ secreted by $\mathrm{A}^{1}$ isolates. Oospore formation by $\mathrm{A}^{1}$ isolates depends on the presence of the receptor to the hormone $\alpha^{2}$ which is formed by $A^{2}$ isolates. The purpose of the present research was to study the effect on hormone production and reception of length of mating, light and temperature.

\section{METHODS}

Phytophthora colocasiae (Pco-1T, $\mathrm{A}^{2}$ ) isolated from taro [Colocasia esculenta (L.) Schott] was used as a hormone producer and $P$. parasitica (P991, $\mathbf{A}^{1}$ ) supplied by G. A. Zentmyer was used as a hormone receptor. Blocks $(20 \times 10 \times 3 \mathrm{~mm})$ of V-8 agar, which consisted of distilled water, $10 \%(\mathrm{v} / \mathrm{v}) \mathrm{V}-8 \mathrm{juice}, 0.02 \%(\mathrm{w} / \mathrm{v})$ $\mathrm{CaCO}_{3}$ and $1.8 \%(\mathrm{w} / \mathrm{v})$ Bacto-agar, were each inoculated with a piece (about $1 \times 1 \times 1 \mathrm{~mm}$ ) of mycelium and incubated in a dark moist chamber at $25^{\circ} \mathrm{C}$. As young cultures of Phytophthora are better hormone producers and old cultures are more responsive to hormones (Ko, 1978), the colonies of $P$. colocasiae and $P$. parasitica were grown for 3 and $6 \mathrm{~d}$, respectively. A culture block of $P$. parasitica placed in the centre of a Petri dish $(100 \times 15 \mathrm{~mm})$ was covered with a polycarbonate membrane (CPR, $0.2 \mu \mathrm{m}, 90 \mathrm{~mm}$ diam.; Nuclepore Corporation, Pleasanton, Calif., U.S.A.) and paired with $P$. colocasiae of the same size on the opposite side of the membrane. After incubation in a moist chamber for 3 to $72 \mathrm{~h}$ at $25^{\circ} \mathrm{C}$ in darkness, the colonies of $P$. colocasiae and membranes were removed, but $P$. parasitica was further incubated for oospore development. The number of 
oospores produced by $P$. parasitica was counted under a microscope, after 4 to $6 \mathrm{~d}$ incubation. In each test the number of oospores produced in 10 microscopic fields per block was counted using a $10 \times$ or $40 \times$ objective. Two replicates per treatment were used and all the experiments were repeated at least twice.

\section{RESULTS AND DISCUSSION}

Mating time. Culture blocks of $P$. colocasiae together with the membranes were removed from four plates after mating for 3, 5, 7, 9, 12, 24, 48 or $72 \mathrm{~h}$. At each period of mating the numbers of sex organs produced by $P$. parasitica on two plates were counted immediately, and the numbers of oospores produced on the other two plates were counted $6 \mathrm{~d}$ after the beginning of mating. All plates were incubated in darkness. No sex organs were observed in matings lasting $7 \mathrm{~h}$ or less (Table 1). However, the amount of hormone produced by $P$. colocasiae in $7 \mathrm{~h}$ was sufficient to stimulate $P$. parasitica to produce 341 oospores $\mathrm{cm}^{-2} 6 \mathrm{~d}$ after the beginning of mating. The results also show that after stimulation by the hormone, the fungus will form sex organs and mature oospores in the absence of the hormone producer. The maximum induction of sex organs occurred in matings lasting $48 \mathrm{~h}$.

Light. To determine the effect of light on hormone production and oospore formation, half the plates were kept under fluorescent light and the other half in darkness during $24 \mathrm{~h}$ matings. Culture blocks of $P$. colocasiae and membranes were removed after mating, and the plates containing culture blocks of $P$. parasitica were further incubated at $25^{\circ} \mathrm{C}$ for $5 \mathrm{~d}$ under light or in darkness for the development of oospores. Results showed that exposure to light during mating greatly reduced the amount of oospores produced, and that the effect of light on oospore formation after hormone stimulation was relatively small (Table 2). In other experiments using a $12 \mathrm{~h}$ mating period, oospore formation after hormone stimulation was significantly decreased by light but the inhibitory effect of light on hormone production was

Table 1. Relationship between the number of sex organs formed by $P$. parasitica $\left(\mathrm{A}^{1}\right)$ and the duration of mating with $P$. colocasiae $\left(\mathrm{A}^{2}\right)$

$\begin{array}{ccc}\begin{array}{c}\text { Duration of } \\ \text { mating }(\mathrm{h})\end{array} & \begin{array}{c}\left.\text { Oogonia (no. } \mathrm{cm}^{-2}\right) \\ \text { at the end of mating } \\ \left(\mathrm{A}^{1} / \mathrm{A}^{2}\right)\end{array} & \begin{array}{c}\text { Oospores }\left(\mathrm{no} . \mathrm{cm}^{-2}\right) \\ 6 \mathrm{~d} \text { after the } \\ \text { beginning of mating } \\ \left(\mathrm{A}^{1}\right)\end{array} \\ 3 & 0 & 1 \\ 5 & 0 & 32 \\ 7 & 0 & 341 \\ 9 & 21 & 2672 \\ 12 & 1634 & 4681 \\ 24 & 6350 & 9517 \\ 48 & 11991 & 12000 \\ 72 & 10616 & 11836\end{array}$

Table 2. Effect of light on oospore formation by $P$. parasitica $\left(\mathrm{A}^{1}\right)$ after induction by $P$. colocasiae $\left(\mathrm{A}^{2}\right)$

\begin{tabular}{|c|c|c|}
\hline $\begin{array}{c}\text { Treatment during } \\
\text { mating } \\
\left(\mathrm{A}^{1} / \mathrm{A}^{2}\right)\end{array}$ & $\begin{array}{l}\text { Treatment during } \\
\text { oospore formation } \\
\left(\mathrm{A}^{1}\right)\end{array}$ & $\begin{array}{c}\left.\text { Oospores (no. } \mathrm{cm}^{-2}\right) \\
\left(\mathrm{A}^{1}\right)\end{array}$ \\
\hline Dark & Dark & $9987 \mathrm{~A}^{*}$ \\
\hline Dark & Light & $8784 \mathrm{~A}$ \\
\hline Light & Dark & $123 \mathrm{~B}$ \\
\hline Light & Light & $45 \mathrm{C}$ \\
\hline
\end{tabular}

* Numbers followed by the same letter are not significantly different at $P=0.05$. 


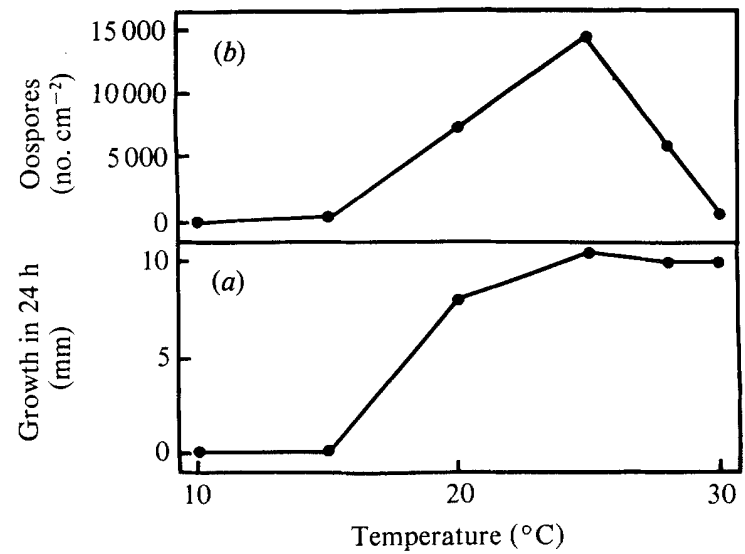

Fig. 1. (a) Effect of temperature on the mycelial growth rate of $P$. colocasiae $\mathrm{A}^{2}$. (b) Effect of temperature on hormone production by $P$. colocasiae $\mathrm{A}^{2}$ as judged by oospore formation in $P$. parasitica $\mathbf{A}^{\mathbf{1}}$.

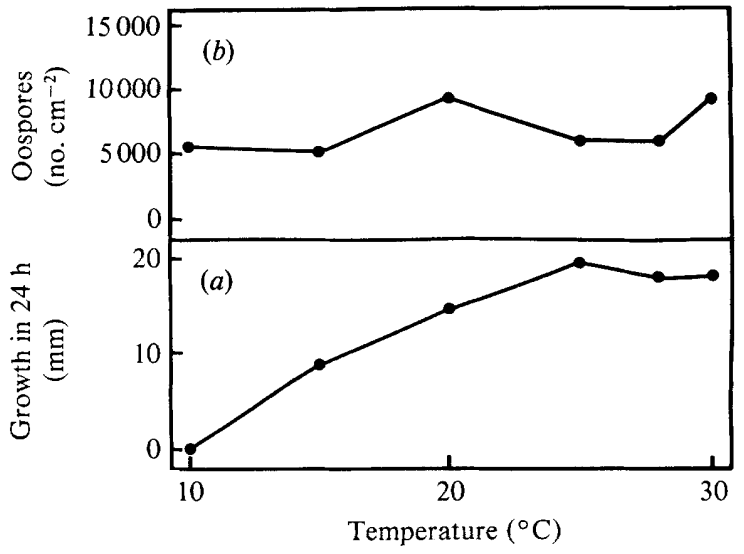

Fig. 2. (a) Effect of temperature on the mycelial growth rate of $P$. parasitica $\mathrm{A}^{\mathbf{1}}$. (b) Effect of temperature on oospore development of $P$. parasitica $\mathrm{A}^{1}$ after induction by $P$. colocasiae $\mathrm{A}^{2}$.

still much greater than that on oospore development. The reported inhibition of oospore production of Phytophthora by light (Brasier, 1969; Harnish, 1965; Honour \& Tsao, 1974; Huguenin \& Boccas, 1971; Klisiewicz, 1970; Ko \& Chang, 1979) is apparently due primarily to suppression of hormone production and secondarily to oospore development.

Temperature. To determine the effect of temperature on hormone production, plates were incubated in darkness at $10,15,20,25,28$ or $30^{\circ} \mathrm{C}$ during $24 \mathrm{~h}$ matings. Culture blocks of $P$. colocasiae and membranes were removed after mating, and plates containing culture blocks of $P$. parasitica were further incubated in darkness at $25^{\circ} \mathrm{C}$ for $3 \mathrm{~d}$ to allow the development of oospores. The effect of temperature on the growth of the mycelium of $P$. colocasiae was determined by incubating at different temperatures V-8 agar plates each containing a culture disc $(5 \mathrm{~mm})$ of $P$. colocasiae in the centre. The linear growth from the disc was measured after $5 \mathrm{~d}$. Growth and hormone production of $P$. colocasiae at 10 and $15^{\circ} \mathrm{C}$ were very poor (Fig. 1). The optimum temperature for growth and hormone production was $25^{\circ} \mathrm{C}$. Although $P$. colocasiae grew well at $30^{\circ} \mathrm{C}$, its ability to produce hormone was very low at this temperature. To determine the effect of temperature on oospore 
formation, plates were incubated in darkness at $25^{\circ} \mathrm{C}$ during $24 \mathrm{~h}$ mating. Culture blocks of $P$. colocasiae and membranes were removed after mating, and plates containing culture blocks of $P$. parasitica were further incubated in darkness at $10,15,20,25,28$ or $30^{\circ} \mathrm{C}$ for $3 \mathrm{~d}$ to allow the development of oospores. The effect of temperature on the growth of $P$. parasitica was determined as described above. Low temperatures prevented the fungus from forming new sex organs after stimulation by hormone, as more oospores were produced at $20,25,28$ and $30^{\circ} \mathrm{C}$ than at 10 and $15^{\circ} \mathrm{C}$ (Fig. 2). The maturation of oospores proceeded at all temperatures tested except $10^{\circ} \mathrm{C}$ which also prevented the growth of $P$. colocasiae. Similar results were obtained in other experiments using a $12 \mathrm{~h}$ mating period. The effect of temperature on hormone production was different from its effect on oospore formation. Hormone production was very poor at $30^{\circ} \mathrm{C}$ (Fig. $1 \mathrm{~b}$ ), but oospore development was favoured at that temperature (Fig. $2 b$ ). The reported temperature effect on sexual reproduction (Brasier, 1969; Honour \& Tsao, 1974; Huguenin \& Boccas, 1971; Klisiewicz, 1970) is apparently the net result of its effect on hormone production and oospore development.

Journal Series Paper No. 2555 of the Hawaii Institute of Tropical Agriculture and Human Resources. This work was supported in part by a grant from the National Science Council (ROC).

\section{REFERENCES}

Brasier, C. M. (1969). The effect of light and temperature on reproduction in vitro in two tropical species of Phytophthora. Transactions of the British Mycological Society 52, 105-113.

HARNISH, W. H. (1965). Effect of light on production of oospores and sporangia in species of Phytophthora. Mycologia 57, 85-90.

Honour, R. C. \& Tsao, P. H. (1974). Production of oospores by Phytophthora parasitica in liquid medium. Mycologia 66, 1030-1038.

Huguenin, B. \& Boccas, B. (1971). Influence of some factors on the formation and germination of oospores in strains of Phytophthora palmivora Butl. Annales de Phytopathologie 3, 353-371.
KLISIEwICZ, J. M. (1970). Factors affecting production and germination of oospores of Phytophthora drechsleri. Phytopathology 60, 17381742 .

Ko, W. H. (1978). Heterothallic Phytophthora: evidence for hormonal regulation of sexual reproduction. Journal of General Microbiology 107, 15-18.

Ko, W. H. (1980). Hormonal regulation of sexual reproduction in Phytophthora. Journal of General Microbiology 116, 459-463.

Ko, W. H. \& Chang, H. S. (1979). Phytophthora katsurae, a new name for Phytophthora castaneae. Mycologia 71, 840-844. 